\title{
SISTEM INFORMASI PENJUALAN NAJLA SASIRANGAN
}

\author{
Silvia Ratna ${ }^{1)}$, Fathur Rahman') \\ 1) Fakultas Teknologi Informasi \\ Universitas Islam Kalimantan Muhammad Arsyad Al Banjari Banjarmasin \\ Email : via.borneo@gmail.com \\ ${ }^{2)}$ Fakultas Teknologi Informasi \\ Universitas Islam Kalimantan Muhammad Arsyad Al Banjari Banjarmasin \\ Email : fathur243@gmail.com
}

\begin{abstract}
Abstrak
Sistem pengelolaan toko dengan menggunakan aplikasi dapat membantu dalam pembuatan laporan dan dalam mengelola data stock barang. Jika pengelolaan data masih digunakan secara manual maka akan rentan untuk kesalahan dan kehilangan data dan sangat sulit jika ingin mendapatkan informasi tentang berapa banyak transaksi yang dilakukan pada hari, minggu maupun bulan apalagi data laporan tahunan, juga jika ingin mengetahui jumlah stock maka sangat lambat sekali karena harus mencari berkas secara manual bahkan memungkinkan sekali ada berkas yang terselip, hilang maupun rusak, demikian juga dengan data supplier yang memasok barang, jika kita mencari data pemasok barang yang sudah lama tidak diorder maka sangat sulit sekali, jika digunakan aplikasi untuk penjualan maka akan mencatat semua transaksi yang pernah dilakukan, jika ingin mencari informasi tentang jumlah stock yang tersedia maka akan secara cepat informasi itu di dapatkan, dengan demikian kinerja karyawan akan meningkat. Aplikasi ini dibuat dengan menggunakan Pemrograman Delphi dan pengolahan data dengan Ms.Acces.
\end{abstract}

Keywords : Ms.Acces, Delphi, Sistem, Informasi

\section{PENDAHUluan}

Pesatnya pertumbuhan dan perkembangan teknologi informasi maka membawa pengaruh pada semakin banyak pula orang yang memanfaatkan kemajuan teknologi informasi ini, hal ini tidak hanya dalam pemenuhan kebutuhan informasi namun juga dalam penyelesaian berbagai masalah dalam kehidupan sehari-hari, namun juga dimanfaatkan untuk meningkatkan kualitas hidupnya. Salah satu permasalahan yang dapat di tangani adalah penilaian kinerja. Di mana dengan kemajuan teknologi informasi maka meningkatkan kemajuan dalam hal peningkatan kualitas kerja.

Perkembangan pemasaran yang berjalan pada toko Najla Sasirangan saat ini masih di nilai kurang memiliki jangkauan yang lebih luas. Dalam memasarkan produk sasirangan yang di miliki setiap perusahaan tentu ingin mempunyai strategi dan sistem pemasaran dengan ciri khas tersendiri yang efektif dan efisien. Namun tidak banyak dari perusahaan yang ada saat ini yang telah mempunyai sistem pemasaran yang efektif untuk mendukung aktifitas perusahaan. Bahkan ada beberapa perusahaan yang tergolong besar yang belum memiliki sistem yang mendukung. Sebagai konsekuensinya dalam sebuah kompetisi yangketat,perusahaan yang belum siap ini akan menemui kesulitan dalam memasarkan produk dan jasa yang di miliki.

Toko Najla Sasirangan adalah sebuah bentuk usaha pribadi dalam bentuk penjualan produk sasirangan,baik produk sudah jadi maupun masih dalam bentuk kain, Saat ini pencatatan atas transaksi pembelian dan penjualan toko masih dilakukan secara manual dan bisa di katakan kurang memadai melihat kenyataan transaksi yang terjadi relatif besar jumlahnya, mengelola data tentang persediaan produk cukup sulit,pertanggung jawaban tidak jelas apabila ada kesalahan, keamanan 
keutuhan data penjualan tidak terjamin,serta data yang di dapat tidak akurat,dan pembuatan laporan pun tidak praktis,sehingga agak menyita waktu bila ingin menghasilkan laporan persediaan dalam waktu singkat.Saatnya pemilik usaha menerapkan pengelolaan data persediaan dan penjualan secara komputerisasi untuk mengatasi masalah hal tersebut.

Untuk memudahkan dalam sistem informasi, maka akan di buat program dengan menggunakan Borland Delphi 7.0 yang dapat mempercepat dan mempermudah dalam pengolahan data dan penyediaan informasi. Salah satu kebutuhan yang sangat besar akan teknologi informasi sekarang ini adalah kebutuhan akan sistem informasi,oleh karena itu saat ini sangat di perlukan penginputan data,pencarian data,pengolahan data yang akurat. Oleh karena itu di perlukan suatu sistem informasi program pengolahan data berbasis komputer yang dapat mempercepat dan mempermudah dalam pengolahan data dan penyediaan informasi.

\section{METODE PENELITIAN}

Pada tahap ini yang sangat mendasar pada pembuatan sistem informasi penjualan barang yaitu pencatatan atas transaksi persediaan dan penjualan toko masih dilakukan secara manual dan bisa dikatakan kurang memadai melihat transaksi yang terjadi sangat besar jumlahnya sehingga tidak dapat memberikan informasi yang cepat jika ingin mendapatkan informasi tentang stock barang dan informasi lainnya.

Adapun proses dalam penelitian ini yaitu :

\subsection{Proses persediaan barang atau stock barang}

Proses persediaan barang atau produk biasanya dimulai dari melihat beberapa banyak barang yang datang atau sudah di buat oleh para pengrajin serta dari hasil penjualannya, apabila barang tersebut sudah hampir habis terjual selanjutnya karyawan membuat rincian produksi barang yang ingin di buat sesuai jumlahnya. Selanjutnya admin membuat laporan kepada pimpinan yang ditulis secara manual dan diberikan kepada bagian pengrajin untuk membuat barang tersebut sesuai dengan rincian barang.

Tahap berikutnya setelah barang jadi bagian produksi membuatkan rincian barang yang sudah selesai di kerjakan kepada admin bagian penjualan, kemudian karyawan membuat data arsip tentang persediaan atau pasokan barang yang dijual serta membuat laporan untuk pimpinan.

\subsection{Proses penjualan barang atau produk}

Pada saat proses data persediaan barang sudah selesai diinformasikan kepada pimpinan, kemudian barang yang sudah jadi tersebut di kirim langsung ke bagian penjualan dimana di situ lah ada proses penjualan barang. Sistem penjualan yang terjadi antara konsumen dan karyawan dengan cara bertemu dan bertatapan langsung di toko tersebut, disana konsumen dilayani sehingga dapat memilih produk-produk yang sudah tersedia.

\subsection{Kesimpulan Analisis}

Setelah melakukan analisis yang ada di Toko Najla Sasirangan, dapat disimpulkan bahwa sistem yang sedang berjalan masih dilakukan secara manual. Salah satu contohnya yaitu dalam mendata persediaan barang, sehingga kurang efektif dalam pembuatan dan penyusunan laporan.

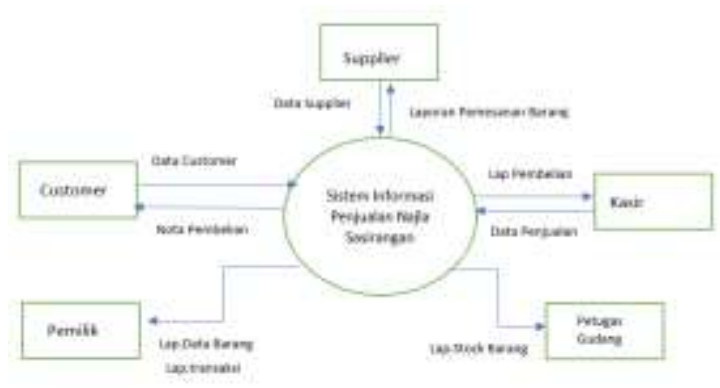

Gambar 1. Diagram Konteks 


\section{HASIL DAN PEMBAHASAN}

\subsection{Antar Muka Sistem}

\section{Form Utama}

Pada bagian ini adalah Form Utama Pada Aplikasi ini Berikut tampilan form utama dapat di lihat pada gambar 4.3 di bawah ini:

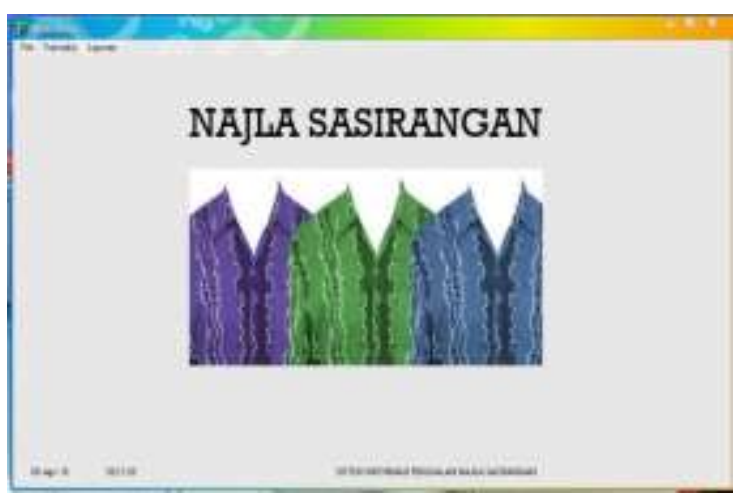

Gambar 2 Form Utama

\section{Form Input Produk}

Form ini berfungsi untuk melihat dan menyimpan data barang, ataupun mengubah data dari barang tersebut, serta menampilkan informasi yang berhubungan dengan data dari barang. Gambar form entry barang adalah sebagai berikut :

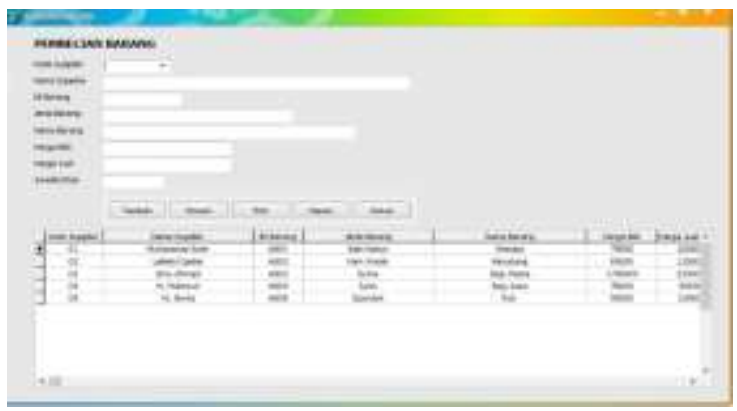

Gambar 3. Form Produk

\section{Form Supplier}

Form ini berfungsi untuk melihat dan menyimpan data pegawai pengrajin, ataupun mengubah data dari pengrajin tersebut serta menampilkan informasi yang berhubungan dengan data dari pengrajin tersebut. Gambar form pegawai pengrajin adalah sebagai berikut

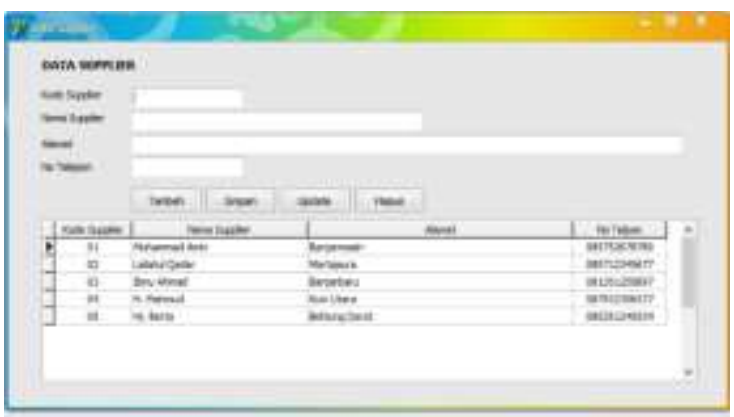

Gambar 4. Form Supplier

\section{Form Transaksi}

Form ini berfungsi untuk melihat dan menyimpan data transaksi pembayaran ataupun mengubah data dari transaksi tersebut, serta menampilkan informasi yang berhubungan dengan transaksi pembayaran dan penjualan. Gambar form nya adalah sebagai berikut :

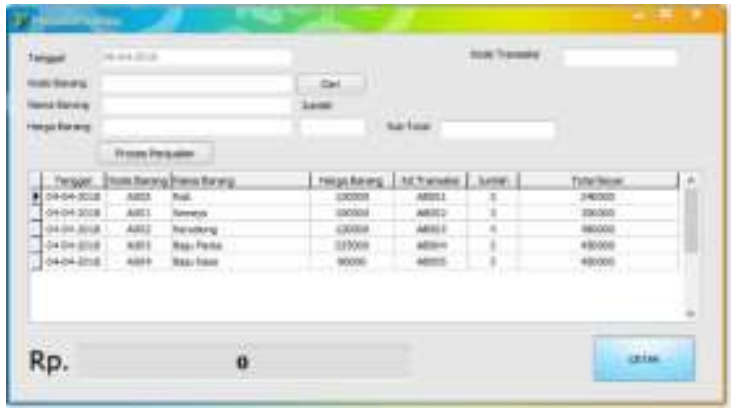

Gambar 5. Form Transaksi

\section{Laporan Nota Penjualan}

Nota penjualan diberikan kepada pelanggan sesudah melakukan transaksi pembayaran. Gambar hasil laporan adalah sebagai berikut :

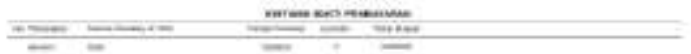

\section{Gambar 6. Laporan Nota Penjualan}




\section{Pembahasan}

Setelah melalui tahapan pengujian aplikasi maka selanjutnya adalah untuk memastikan apakah sistem informasi sesuai dengan rencana perancangan sistem. Hal ini dapat diperlihatkan dengan hasil yang sesuai dengan yang diharapkan dan meminimalkan kesalahan. Untuk pengujian kali ini menggunakan data sampel penjual dan beberapa pembeli untuk melihat hasil langsung dapat diberikan masukan sebelum aplikasi digunakan.

\section{KESIMPULAN}

Berdasarkan hasil dari penelitian yang telah di bahas dalam pembahasan maka dapat diambil kesimpulan yang nantinya diharapkan bermanfaat dalam penerapan Sistem Informasi Penjualan Sasirangan Pada Toko Najla Sasirangan, maka dapat diambil kesimpulan sebagai berikut :

1. Sistem Informasi persediaan barang dan penjualan produk pada toko Najla Sasirangan yang dibangun dalam bentuk desktop ini dapat membantu konsumen yang ingin melakukan pembelian produk sasirangan di Toko Najla.

2. Adanya sistem penjualan produk dapat digunakan untuk membantu pengelola Toko Najla Sasirangan dalam mengelola usahanya sehingga lebih meningkatkan kinerja karyawan.

\section{Saran}

Adapun saran-saran yang diusulkan oleh penulis setelah membuat sistem informasi yang diusulkan adalah sebagai berikut :

1. Dengan adanya sistem Informasi persediaan dan penjualan produk sasirangan, maka disarankan adanya pengembangan lebih lanjut untuk merancang sistem yang berbasis web sehingga mampu mempromosikan toko dan produk sasirangan.

2. Mengembangkan menjadi aplikasi penjualan berbasis online sehingga mampu melayani pelanggan secara maksimal.

\section{REFERENSI}

Jogiyanto, HM. 1997. Sistem Informasi Berbasis Komputer Edisi Ke-2 Yogyakarta: BPFE Yogyakarta.

Jogiyanto, HM. 2001. Analisa Dan Desain Sistem Informasi Edisi Kedua. Yogyakarta: Andi Offset.

Kristanto, Andri. 2003. Perancangan Sistem Informasi dan Aplikasinya. Yogyakarta: Gava Media.

Alam, M. Agus J. 2003, Mengolah Database Dengan Borland Delphi 7, PT. Elex Media Komputindo.

Indrajani, S.Kom.,MM. 2017, Database Design. Jakarta: PT. Elex Media Komputindo. 